Original Article

\title{
A review on preclinical studies conducted with Homeopathic medicine Cephalandra indica as an anti-hyperglycemic agent
}

\author{
Mitesh Santosh Wakte 1, Mugdhakumari R Patel1, Sharda Shankar Gowda1, Suraj Singh \\ Bhadoria 1, Niranjan Joshi 1, Arun Bhargav Jadhav 2, Aditya Dilipkumar Patil*1
}

${ }^{1}$ Post Graduate scholar, Department. Of Homeopathic pharmacy, Bharati Vidhyapeeth (Deemed to be university) Homeopathic medical college and post graduate research centre, Pune, Maharashtra, India

${ }^{2}$ Head of institute, Bharati Vidhyapeeth (Deemed to be university) Homeopathic medical college and post graduate research centre, Pune, Maharashtra, India

*correspondence author: dradityapatil108@gmail.com

\begin{abstract}
Background Diabetes Mellitus is a metabolic disorder that affects the secretion of insulin from pancreas leading to hyperglycemia. If uncontrolled leads to complications triggered by free radical formed after oxidative stress. Homeopathic medicine Cephalandra Indica has shown antidiabetic activity in various potencies performed on preclinical studies on diabetic rat model. The present review highlights the pharmacological profile of homeopathic preparations from Cephalandra Indica on preclinical studies and calculating the probable human equivalent dosage from preclinical studies for the pilot studies. Methods Articles published between January 1988 and December 2018 were included in this review. Databases like PubMed - Medline, Google scholar were used for collecting the articles. Keywords like 'Homeopathy' or 'Homoeopathy', 'in vitro', 'in vivo' and 'Cephalandra Indica' were used. SABEH criteria was implemented for assessing the methodology quality of articles. Results Seven full text articles were included in review which had six in vivo studies and one in vitro study. This review article provided the scientific validation of high diluted homeopathic medicines pharmacological activity of $C$. indica and probable mechanism of action confirmed through preclinical studies. Conversion of dosage from animal model to human dosage for pilot studies has been hypothetically proposed. Conclusion Homeopathic medicine $C$. indica has a therapeutic and safety profile with no toxicity observed in preclinical studies. The proposed hypothesis of conversion of dosage needs to be validated for further studies.
\end{abstract}

Keywords: Cephalandra Indica, diabetes mellitus, homeopathy, preclinical studies, SABEH.

\section{Introduction}

Diabetes Mellitus (DM) is a metabolic disorder which leads to hyperglycemia with disproportion of protein, carbohydrate and fat metabolism resulting in depletion of production of insulin from pancreas (defects in insulin secretion), or when insulin lacks sensitivity within body (defect in insulin action), or both (1). Prolonged state of hyperglycemia leads to development of diabetic complications through oxidative stress and accompanied by chronic inflammation which are life threatening $(2,3)$. Oxidative stress causes the generation of free radicals which leads to changes in glucose oxidation, non-enzymatic glycation of proteins etc. Free radicals affects cellular organelles and lipid peroxidation, providing damage to system of the enzyme and forming the major pathogenesis of diabetes and its complications (4). 
Alternative therapies like homeopathy have been widely used for the treatment of DM. The market for homeopathic medicine is expected to grow at a Compound Annual Growth Rate (CAGR) of 12.5\% (5). Homeopathic drugs are included in Drugs and Cosmetics Act, 1940 in Indian government regulatory agency, so it becomes mandatory to generate therapeutic profile, mechanism of action, toxicity and safety of these drugs included under scheduled ' $Y$ ' of Drug Controller General of India. Pre-clinical trials therefore play a major role before administering drug in healthy human volunteers for drug proving (6).

Extensive review study has been performed on crude extract of Cephalandra Indica (C. indica) in terms of pharmacognosy, phytochemical constituents and pharmacological properties (7-10). As such there had been no any previous review conducted on homoeopathic medicine $C$. indica action and its potencies on diabetes.

C. indica commonly known as little gourd belongs to family Cucurbitaceae (11). $C$. indica has antihyperglycemic profile in Ayurvedic system of medicine (12). Fresh juice from the roots of $C$. indica is used to control diabetes. Tincture prepared from leaves of $C$. indica is administered for treatment of gonorrhea. $C$. indica also has antispasmodic activity and also found to be useful in various skin disorders (13-15). Phytoconstituents majorly found in aerial parts of $C$. indica are Cephalandrol, Heptacosane, Bsitosterol, Tritriacontane, alkaloids and Cephalandrine (alpha and beta) (16). C. indica fruits constitutes Apo-6- lycopenal, B-carotene, Lycopene, Taraxerol, Taraxerone, and (24R)-24-ethylcholest-5-en-3b-ol glucoside and Cryptoxanthin (17-19) The present review highlights the pharmacological profile of homeopathic preparations $C$. indica on preclinical studies and calculating the probable human equivalent dosage (HED) from preclinical studies for the pilot studies.

\section{Materials and methods}

Research manuscript published between January 1988 and December 2018 were identified for further review. Search database included manuscript from Pubmed-Medline, Google scholar with keywords 'Homeopathy' or 'Homoeopathy', 'in vitro', 'in vivo' and 'Cephalandra Indica'. Manuscript selected was in English language which was available in full text. The selection period was restricted to last 30 years as there has been rapid improvement in methodology all through this period. Score for assessment of biological experiment on homoeopathy (SABEH) was designed and modified for assessment of methodological quality which had following criteria: a) Defined Objectives b) Control c) Blinding of measurement of outcomes d) Randomization e) Consistency f) Experiment standardization g) Statistical analysis h) Result (20).

\section{Results}

SABEH criteria was designed in order to overcome the quality assessment of a research manuscript. Seven original full text research papers were identified by the above mentioned keywords. Out of which 6 in vivo studies and 1 in vitro study were identified. The details are mentioned in Table 1 and Table 2 represents the data of $C$. indica dosage administering.

C. indica MT (Mother Tincture), 6C and 30C potency was widely used in rat model experiments. Statistical parameter one way ANOVA and student t-test were found repeatedly in use in research manuscript. $C$. indica was measuredly tested on antihyperglycemic, antioxidant, advance glycation end products, lipid and cholesterol. 
Table 1 - Summary of preclinical studies conducted on homeopathic medicine $C$. indica.

\begin{tabular}{|c|c|c|c|c|c|c|c|c|c|}
\hline $\begin{array}{l}\text { SR. } \\
\text { NO }\end{array}$ & AUTHORS NAME & SPECIES/CULTURE & POTENCY & VARIABLES & RESULT & CONTROL & STATICALS & REFRENCE & YEAR \\
\hline 1 & D.P. Rastogi et.al. & Albino rats & $\begin{array}{l}\text { C. indica MT } \\
(25 \mu \mathrm{ml} / 100 \\
\text { gbw }) \\
50 \mu \mathrm{ml} / 100 \\
\text { gbw } \\
75 \mu \mathrm{ml} / 100 \\
\text { gbw } \\
100 \mu \mathrm{ml} / 100 \\
\text { gbw }\end{array}$ & $\begin{array}{l}\text { 1. Blood Sugar Level } \\
\text { (fasting in mg/dl) } \\
\text { 2. Beta cell count per islet } \\
\text { area in cross section }\left(\mathrm{mm}^{2}\right. \\
\text { x 350) } \\
\text { 3.ED 50 - ED100 }\end{array}$ & $\begin{array}{l}\text { In vitro study } \\
\text { suggested neuro - } \\
\text { endocrinological } \\
\text { mechanism of } C \text {. indica } \\
\text { MT in stabilizing in } \\
\text { blood sugar level. } \\
\text { Anti-hyperglycemic } \\
\text { Activity established by } \\
\text { C. indica MT }\end{array}$ & $\begin{array}{l}\text { - Physiological } \\
\text { normal saline } \\
(0.9 \% \mathrm{w} / \mathrm{v}) \\
-41 \% \text { alcohol } \\
\text { v/v } \\
\text { - Alloxan } \\
\text { - Insuline } \\
40 \mathrm{unit} / \mathrm{ml} \\
\text { - Glibenclamide } \\
\text { (Daonil) } \\
\text { - Tolbutamide } \\
\text { (Rastinon) }\end{array}$ & $\begin{array}{l}\text { Mean + } \\
\text { Standard } \\
\text { error mean / } \\
\text { students t- } \\
\text { test }\end{array}$ & 21 & 1988 \\
\hline 2 & Sathish Sampath et.al. & $\begin{array}{l}\text { Wistar strain } \\
\text { albino Rats }\end{array}$ & $\begin{array}{l}\text { S. } \\
\text { jambolanum } \\
\text { MT (20 } \\
\mu \mathrm{l} / 100 \text { grm) } \\
\text { S. } \\
\text { jambolanum } \\
6 \mathrm{C}(20 \mu \mathrm{l}) \\
\mathrm{S} . \\
\text { jambolanum } \\
30(20 \mu \mathrm{L}) \\
\text { C. indica } \mathrm{MT} \\
(20 \mu \mathrm{l} / 100 \\
\text { gbw) } \\
\text { C. indica 6C } \\
(20 \mu \mathrm{l} / \mathrm{gbw}) \\
\text { C. indica } 30 \mathrm{C} \\
(20 \mu \mathrm{L} / \mathrm{gbw})\end{array}$ & $\begin{array}{l}\text { 1. Fasting Blood Glucose } \\
\text { 2. Radioumunoassay insulin } \\
\text { (IR,Akt,GLUT4) } \\
\text { 3.Lipid profile } \\
\text { 4.mRNA expression } \\
\text { analysis } \\
\text { 5. Protein isolation } \\
\text { 6. Western blot analysis }\end{array}$ & $\begin{array}{l}\text { S. jambolanum and } C \text {. } \\
\text { indica Exhibit } \\
\text { antidiabetic effect by } \\
\text { favoring glucose } \\
\text { uptake and oxidation } \\
\text { in skeletal muscles } \\
\text { through improvement } \\
\text { in said variables. }\end{array}$ & $\begin{array}{l}\text { Plane control } \\
\text { Metformin (50 } \\
\mathrm{mg} / \mathrm{kg})\end{array}$ & $\begin{array}{l}\text { One way } \\
\text { analysis of } \\
\text { variance } \\
\text { (ANOVA) } \\
\text { duncan } \\
\text { multiple } \\
\text { range test }\end{array}$ & 22 & 2013 \\
\hline 3. & Arindam Pal et.al & $\begin{array}{l}\text {-Mouse fibroblast } \\
3 \mathrm{~T} 3 \text { cells } \\
\text { Male Wistar albino } \\
\text { rats }\end{array}$ & $\begin{array}{l}\text { C. indica MT } \\
\text { (6C, } 24 \mathrm{X}, 12 \mathrm{C} \\
\text { and } 30 \mathrm{C}) \\
(75 \mu \mathrm{L} / 100 \\
\text { g) }\end{array}$ & $\begin{array}{l}\text {-Determination of blood } \\
\text { glucose and cholesterol } \\
\text { level } \\
\text {-Liver and pancreatic } \\
\text { biopsy } \\
\text {-Glucose uptake assay }\end{array}$ & $\begin{array}{l}\text { The present study } \\
\text { clearly indicates a } \\
\text { significant antidiabetic } \\
\text { effect of } \\
\text { C. indica and lends } \\
\text { support for its usage }\end{array}$ & $\begin{array}{l}\text {-Sreptozotocine } \\
\text {-Placebo control } \\
40 \% \text { ethanol } \\
\text { - Glibenclamide }\end{array}$ & $\begin{array}{l}\text { Student's t- } \\
\text { test }\end{array}$ & 23 & 2013 \\
\hline
\end{tabular}


International Journal of High Dilution Research 2019; 18(3-4):35-46

Available online at www.highdilution.org

\begin{tabular}{|c|c|c|c|c|c|c|c|c|c|}
\hline & & & & $\begin{array}{l}\text {-Identification of Phenolics } \\
\text { by HPTLC (high } \\
\text { performance thin layer } \\
\text { chromatography) } \\
\text {-LC- MS/MS analyses of } \\
\text { extracted phenolics } \\
\end{array}$ & $\begin{array}{l}\text { as a homoeopathic } \\
\text { medicine. }\end{array}$ & & & & \\
\hline 4. & $\begin{array}{l}\text { Subasri } \\
\text { Muthuviveganandavel } \\
\text { et.al }\end{array}$ & Male albino rats & C. indica $\mathrm{MT}$ & $\begin{array}{l}\text {-Blood Serum glucose } \\
\text {-protein } \\
\text {-Cholesterol } \\
\text {-Reduces glutathione } \\
\text {-Triglyceride } \\
\text {-Lipid peroxidase } \\
\text {-Asparates } \\
\text { aminotransferance } \\
\text {-Alanine aminotransferase } \\
\text {-Alkaline phophates } \\
\\
\text { Hematology parameters } \\
\text { Packed cell volume } \\
\text { White Blood cells } \\
\text { Lymphocytes (\%) } \\
\text { Neutrophils (\%) } \\
\text { Hemoglobin (g \%) }\end{array}$ & $\begin{array}{l}\text { This study shows some } \\
\text { positive role of } C \text {. } \\
\text { indica (MT)for } \\
\text { decreasing blood } \\
\text { serum } \\
\text { sugar and cholesterol } \\
\text { level }\end{array}$ & $\begin{array}{l}\text { Sham Control } \\
\text { Placebo Control } \\
(40 \% \text { ethanol) }\end{array}$ & $\begin{array}{l}\text { Student's t- } \\
\text { test }\end{array}$ & 24 & 2014 \\
\hline 5 & $\begin{array}{l}\text { Rashmi Santosh Tupe } \\
\text { et.al }\end{array}$ & $\begin{array}{l}\text { Human } \\
\text { Erythrocytes }\end{array}$ & $\begin{array}{l}\text { C. indica MT } \\
\text {-S. } \\
\text { jambolanum } \\
\text { Q } \\
\text { C. indica } \\
200 \mathrm{C} \\
-\mathrm{S} \text {. } \\
\text { jambolanum } \\
\text { 200C } \\
\text { C. indica 30C } \\
\text {-S. } \\
\text { jambolanum }\end{array}$ & $\begin{array}{l}\text { Albumin Glycation. } \\
\text { 1.Determination of } \\
\text { glycation markers: } \\
\text { Estimation of fructosamine) } \\
\text { Estimation of protein } \\
\text { carbonyls) } \\
\text { Estimation of protein } \\
\text { bound sugar) } \\
\text { 2.Determination of } \\
\text { structure modification: } \\
\text { Estimation of free thiol } \\
\text { Estimation of free amino } \\
\text { group } \\
\text { 3.Determination of phyto } \\
\text { chemical } \\
\text { Total phenolic Contains }\end{array}$ & $\begin{array}{l}\text { 1. All the } \\
\text { homoeopathic } \\
\text { Potencies had different } \\
\text { modes of action on } \\
\text { albumin glycation } \\
\text { modification in human } \\
\text { erythrocytes in-vitro }\end{array}$ & $\begin{array}{l}\text { Positive control } \\
\text { glycated Samples }\end{array}$ & $\begin{array}{l}\text { Mean Value } \\
\text { standard } \\
\text { deviation. }\end{array}$ & 25 & 2015 \\
\hline
\end{tabular}


International Journal of High Dilution Research 2019; 18(3-4):35-46

Available online at www.highdilution.org

\begin{tabular}{|c|c|c|c|c|c|c|c|c|c|}
\hline & & & & $\begin{array}{l}\text { Determination flavonoids } \\
\text { Determination of glycosides } \\
\text { Cellular Study : } \\
\text { 1.Erythrosytes with } \\
\text { glycated BSA samples- } \\
\text { 2.Hemolysis Test } \\
\text { 3.Intracellular anti-oxidant } \\
\text { activity of erythrocytes }\end{array}$ & & & & & \\
\hline 6. & Lalit Kishore et.al. & Male Wistar rats & $\begin{array}{l}\text { C. indica (MT } \\
, 6 \mathrm{C} \text { and } 30 \mathrm{C} \text { ) } \\
2 \mathrm{ml} / \mathrm{kg}\end{array}$ & $\begin{array}{l}\text { 1.Body weight, blood } \\
\text { glucose and serum insulin } \\
\text { estimation } \\
\text { 2.Behavioral assessment } \\
\text { a. Assessment of } \\
\text { thermal hyperalgesia } \\
\text {-Tail-immersion } \\
\text { (hot water) test } \\
\text {-Hot-plate test } \\
\quad \text { b-Assessment of } \\
\text { mechanical } \\
\text { hyperalgesia } \\
\text { c. Assessment of } \\
\text { allodynia } \\
\text { d. Motor nerve } \\
\text { conduction } \\
\text { velocity. } \\
\text { e. Biochemical } \\
\text { analysis. } \\
\text {-Estimation of } \\
\text { superoxide dismutase. } \\
\text { - Estimation of } \\
\text { reduced } \\
\text { Glutathione }\end{array}$ & $\begin{array}{l}\text { homeopathic potencies } \\
\text { of } C \text {. indica have } \\
\text { protective effect } \\
\text { against diabetic } \\
\text { neuropathy (DN) via } \\
\text { inhibition } \\
\text { of oxidative stress and } \\
\text { AGE's }\end{array}$ & $\begin{array}{l}\text {-Streptozotocine } \\
\text {-Nikotinamide }\end{array}$ & $\begin{array}{l}\text { Mean } \pm \text { SEM } \\
\text { and one-way } \\
\text { Analysis of } \\
\text { variance } \\
\text { (ANOVA) was } \\
\text { used for } \\
\text { statistical } \\
\text { analysis. } \\
\text { ANOVA was } \\
\text { followed by } \\
\text { Tukey's as } \\
\text { post hoc } \\
\text { multiple } \\
\text { comparison } \\
\text { Test. }\end{array}$ & 26 & 2017 \\
\hline
\end{tabular}


International Journal of High Dilution Research 2019; 18(3-4):35-46

Available online at www.highdilution.org

\begin{tabular}{|c|c|c|c|c|c|c|c|c|c|}
\hline & & & & $\begin{array}{l}\text { f. Nitrite estimation. } \\
\text { g. Ages estimation in } \\
\text { sciatic nerve }\end{array}$ & & & & & \\
\hline 7. & Kishore L. et.al & $\begin{array}{l}\text {-Male Wistar rats } \\
\text {-Erythrocytes }\end{array}$ & $\begin{array}{l}\text { C. indica MT } \\
\text { C. indica 6C } \\
\text { C. indica 30C }\end{array}$ & 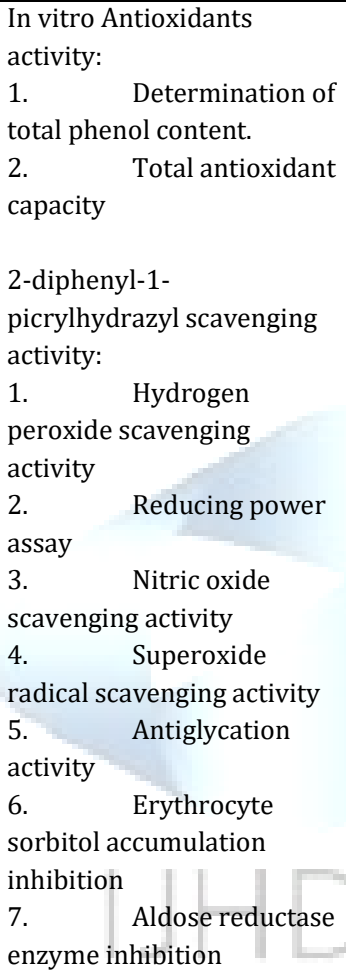 & $\begin{array}{l}\text { Defensive effects } \\
\text { of homoeopathic } \\
\text { preparation of } C \text {. indica } \\
\text { may } \\
\text { suggest its use for the } \\
\text { attenuation of } \\
\text { oxidative stress and } \\
\text { Diabetic complications. }\end{array}$ & $\begin{array}{l}\text { Parameter } \\
\text { describe } \\
\text { individually on } \\
\text { different } \\
\text { variables }\end{array}$ & $\begin{array}{l}\text { Mean }+ \\
\text { standard } \\
\text { deviation. }\end{array}$ & 27 & 2018 \\
\hline
\end{tabular}


International Journal of High Dilution Research 2019; 18(3-4):35-46

Available online at www.highdilution.org

Table 2 - Score for assessment of biological experiment on homeopathy (SABEH) included studies.

\begin{tabular}{|c|c|c|c|c|c|c|c|c|c|c|c|}
\hline S.NO & AUTHOR & $\begin{array}{l}\text { OBJECTIVES } \\
\text { (1) }\end{array}$ & $\begin{array}{l}\text { CONTROLS } \\
\text { (1) }\end{array}$ & $\begin{array}{l}\text { BLINDING } \\
\text { (1) }\end{array}$ & $\begin{array}{l}\text { RANDOMIZATION } \\
\text { (1) }\end{array}$ & $\begin{array}{l}\text { CONSISTENCY } \\
\text { (1) }\end{array}$ & $\begin{array}{c}\text { EXPERIMENT } \\
\text { STANDARIZATION } \\
(1,1)\end{array}$ & $\begin{array}{l}\text { STATISTICS } \\
\text { (1) }\end{array}$ & $\begin{array}{c}\text { RESULT } \\
\text { INTERPRETATION } \\
\text { (1) }\end{array}$ & $\begin{array}{l}\text { SABEH } \\
(9)\end{array}$ & REFERENCES \\
\hline 1 & D.P. Rastogi et.al. & 1 & 1 & 0 & 0 & 1 & 1,1 & 1 & 1 & 7 & 21 \\
\hline 2 & Sathish Sampath et.al. & 1 & 1 & 0 & 0 & 1 & 1,1 & 1 & 1 & 7 & 22 \\
\hline 3 & Arindam Pal et.al & 1 & 1 & 0 & 0 & 1 & 1,1 & 1 & 1 & 7 & 23 \\
\hline 4 & $\begin{array}{l}\text { Subasri } \\
\text { Muthuviveganandavel } \\
\text { et.al }\end{array}$ & 1 & 1 & 0 & 0 & 1 & 0 & 1 & 1 & 5 & 24 \\
\hline 5 & $\begin{array}{l}\text { Rashmi Santosh Tupe } \\
\text { et.al }\end{array}$ & 1 & 1 & 0 & 0 & 1 & 1,1 & 1 & 1 & 7 & 25 \\
\hline 6 & Lalit Kishore et.al. & 1 & 1 & 0 & 0 & 1 & 1,1 & 1 & 1 & 7 & 26 \\
\hline 7 & Kishore L. et.al & 1 & 1 & 0 & 0 & 1 & 1,1 & 1 & 1 & 7 & 27 \\
\hline
\end{tabular}




\section{Discussion}

Homeopathic medicines in these recent times are tested on various preclinical studies. Earlier research conducted on this high dilution medicine showed efficacy in various preclinical studies. Similarly, homeopathic preparation of $C$. indica in its various potencies had been used in preclinical studies for exploring its antioxidant properties with antihyperglycemic activity. The present review highlights the formulation of probable dosage required for testing homeopathic medicine in diabetic animal model studies and provides information on pharmacological activity of homeopathic preparation $C$. indica in its various potencies.

The quality of research manuscript was assessed by SABEH criteria modified through previous conducted systematic review. The SABEH criteria include details (Objectives, Controls, Blinding, Randomization, Consistency, Experiment Standardization, Statistical analysis, Results interpretation.), each representing score of 1 , which gives sum of 9. Paper having SABEH score higher than 5 had been included in the review study (20).

According to the study conducted by D.P. Rastogi et al., $C$. indica Mother Tincture when administered in alloxan-induced diabetic rats showed a significant control of blood sugar level within fourteen to twenty days after withdrawal of the drug. Regeneration of pancreatic beta cells was confirmed through histopathological studies which lowered the blood sugar level through the hypothalamohypophysial-pancreatic axis, which indirectly release inhibitory factors from hypothalamic neurons, inhibiting the secretion of growth hormone and triggering insulin secretion from beta cells (21).

Sathish Sampath et al. conducted the molecular study identifying the antidiabetic effects of homeopathic preparations of S. jambolanum and C. indica in their mother tincture, 6C and 30C through skeletal muscle of rats with high fat and fructose-induced type- 2 diabetes mellitus. $S$. jambolanum and $C$. indica in their mother tincture, $6 \mathrm{C}$ and $30 \mathrm{C}$ were tested on parameters like serum insulin and insulin signaling molecules in the skeletal muscle (gastrocnemius), insulin receptor (IR), v-akt murine thymoma viral oncogene homolog (Akt), p-Aktser473 and glucose transporter-4 (GLUT4) protein expression, fasting blood glucose and lipid profile. Homeopathic preparations of $S$. jambolanum and $C$. indica, showed antidiabetic effects in ultramolecular dilutions by improving insulin action via activation of insulin signaling molecules in skeletal muscle of type- 2 diabetic rats (22).

The study conducted by Arindam Pal et al. investigated the effects of $C$. indica MT and potencies in streptozotocin (STZ)-induced diabetic Wistar rats. Parameters like body weight, cholesterol level, blood glucose level, and beta-cells of pancreatic islets of Langerhans were measured, with this mouse fibroblast (3T3) cell line were used to study the Glucose uptake mechanism. $C$. indica in MT and various potency showed regeneration of beta-cells in the pancreas which further significantly reduced the blood glucose level with regain of body weight by reducing uptake of glucose confirmed in $3 \mathrm{~T} 3$ cell line (23).

According to the study conducted by Subasri Muthuviveganandavel et al., $C$. indica MT was studied on parameters like cholesterol, protein, glucose and triglycerides via blood serum of male albino rat. C. indica MT showed low-dose acute effect on the above mentioned parameters (24).

Rashmi Santosh Tupe et.al had worked on S. jambolanum and C. indica (MT, 30C, 200C) respectively in evaluating cellular protection ability in human erythrocytes via glycation induced structural modifications in vitro. Parameters of glycation (carbonyls, bound sugar, fructosamines), structural 
modifications (thiol group and free amino) were tested. Phytochemical characterization (total phenolic, flavonoids and glycosides contents) was also performed. The homeopathic preparations especially of $S$. jambolanum in human erythrocyte in vitro prevented glycation induced albumin modifications and subsequent toxicity (25).

Lalit Kishore et al. had conducted research on DN in Wistar rats via streptozotocin induced experimental diabetes model which evaluated the effect of homeopathic preparation of $C$. indica (family Cucurbitaceae) MT, 6C and 30C potencies. Parameters for DN were studied through thermal (tail immersion and hot plate method) and mechanical hyperalgesia (randell-sellito analgesiometer test), motor nerve conduction velocity (MNCV), allodynia (von frey hair test) and oxidativenitrosative stress. Tissue antioxidant enzymes (TBARS, GSH, and SOD) levels were also measured to assess the oxidative stress with levels of advanced glycation end products (AGEs) in sciatic nerve along with nitrite estimation. $C$. indica significantly reduced oxidative stress and AGESs level in sciatic nerve with protective effect against DN (26).

Another study conducted by Lalit Kishore et al. was designed to evaluate action of $C$. indica (MT, 6C and 30C) against oxidative stress. The antioxidant activity was confirmed via 2,2-diphenyl-1-picrylhydrazyl radical, hydrogen peroxide, nitric oxide and superoxide radical scavenging activity. Phyto-constituents like total phenol content, gallic acid, ascorbic acid were measured respectively within potencies. Homoeopathic preparations of $C$. indica (MT, 6C and 30C) showed protective effect against oxidative stress (27).

Future perspective - (Dose escalation protocol, conversion of animal model to human dosage)

Homeopathic system is purely on the concept of drug proving performed on healthy volunteers. Drug action of homeopathic medicine is interpreted in the form of subjective analysis of perception felt by volunteer. The dosage parameter used in proving is still an empirical source which needs to be standardized for safety of human consumption. Although the dilutions of homeopathic medicines are above the Avogadro's equation which ensure a less chance of observing adverse event as compared to those of conventional ones. Preclinical studies might be a essential guide for predicting dose of first in human or initial phase studies or in drug proving trial, which might be used as standard protocol on the basis of NOAEL. Conversion model bases on body surface area and inter species relation through conversion factor equation. The above mentioned studies performed with $C$. indica confirm no toxicity after administration of MT, potency when compared with standard control and vehicle control. Further studies with parenteral route of administration might be a new outlook for administration of homeopathic medicines and comparing its efficacy with the oral intake in animal model experiments of $C$. indica.

\section{Conclusion}

Homeopathic medicine $C$. indica has a therapeutic and safety profile with no toxicity observed in preclinical studies. The proposed hypothesis of conversion of dosage needs to validate in first phase of diabetic trial.

\section{Acknowledgement}


Authors are thankful to Bharati Vidhyapeeth (Deemed to be university) Homoeopathic Medical College and research Centre for providing necessary infrastructure and research facilities. Authors would like to extent there for most Byline to Dr. Anita Sardar Patil (PG Coordinator) for the unmatched support, Dr. Manisha Prashant Gajendragadkar for constant check on the progress of the project, Dr. Chetan Hanumantroa Shinde, for minor detailing and correction and Dr. Tejas Prabhakar Gosavi for his relentless guidance.

\section{Conflict of Interest}

Authors Declares no any conflict of interest.

\section{References}

[1] Kaur N, Kishore L, Singh R. Attenuating diabetes: What really works?, Curr Diabetes Rev. 12 (2016) 259-278.

[2] Smith HS, Argoff CE. Pharmacological treatment of diabetic neuropathic pain, Drugs 71 (2011) $557-589$.

[3] Sonnett TE, Levien TL, Gates BJ, Robinson JD, Campbell RK. Diabetes mellitus, inflammation, obesity: proposed treatment pathways for current and future therapies, Annal. Pharmacother. 44 (2010) 701-711.

[4] Kishore L, Singh R. Effects of different homeopathic potencies of C. Indicain treatment of neuropathic pain in streptozotocin induced diabetes, Bulletin of Faculty of Pharmacy, Cairo University 55 (2017) 273-280.

[5] Homeopathic Medicine Market Research Report - Global forecast till 2023 ID: MRFR/HC/3002-HCRR, May, 2019, Region: Global, 206 pages, Half-Cooked Research Reports.

[6] Gupta P, Sundaram EN, Sharma M, Prajapati S, Arya BS, Khurana A, et al. Pre-clinical pharmacology: An important aspectin homoeopathic research. Indian J Res Homoeopathy 2018;12:164-79.

[7] Alagar Raja M, Sushma K, Banji D, Rao KNV, Selvakumar D. Evaluation of standardisation parameters, pharmacognostic study, preliminary phytochemical screening and in vitro antidiabetic activity of Coccinia indica fruits as per WHO guidelines. Indian J. Pharm. Biol. Res.2014; 2(3):5464.

[8] Deokate UA, Khadabadi SS. Pharmacology and phytochemistry of Coccinia indica, Journal of Pharmacognosy and Phytotherapy. 2011; 3:155-159.

[9] Jamwal A, Kumar S. A review of Cephalandra indica Naud, Indian Journal of research in pharmacy and Biotechnology. 2015; 3:256-280. 
[10] Mayank K, Shashi A. Morphology. pharmacological activity, pharmaceutical preparation, doses and side effect of Coccinia indica (Wight \& Arn.): An overview, Journal of Coastal Life Medicine, 2013; 1(4):330-336.

[11] Chopra RN, Chopra IC, Handa KL, Kapur LD. Medicinal plants in diabetes, in: P. Gupta (Ed.), Indigenous Drugs of India, 2nd Ed., U.N. Dhar \& Sons Ltd, Calcutta, 1958, pp. 314-316.

[12] Nandakarni AK. The Indian Materia Medica, Popular publication, Bombay, 1976, 300.

[13] Chandrasekar B, Mukherjee B, Mukherjee SK. Blood sugar lowering potentiality of selected Cucurbitaceae plants of Indian origin, Indian J. Med. Res. 90 (1989) 300-305.

[14] Rahman R, Shibib BA, Khan LA. Hypoglycaemic activity of Coccinia indica and Momordica charantia in diabetic rats: Depression of the hepatic gluconeogenic enzymes glucose-6-phosphatase andfructose-1,6- bisphosphatase and elevation of both liver and redcell shunt enzyme glucose-6-phosphate dehydrogenase, Biochem. J. 292 (1993) 267-270.

[15] Platel K, Srinivasan K. Plant foods in the management of diabetes mellitus: Vegetables as potential hypoglycemic agents, Nahrung 41 (1997) 68-74.

[16] Dhargalkar IM, Guha SK. Nutritional values of Indian vegetables, J. Proc. Inst. Chemists 31 (1959) 109-112.

[17] Basu K, Ghosh BK. Chemical investigation of Coccinia indica, Trans. Bose Res. Inst. 35 (1972) 43-44.

[18] Bhakuni DS, Srivastava SN, Sharma VN, Kaul KN. Chemical examination of the fruits of Coccinia indica, J. Sci. Ind. Res. B Phys. Sci. 21 (1962) 237-238.

[19] Kundu S, Ray AB. Chemical examination of Coccinia indica fruits, J. Indian Chem. Soc. 64 (1987) 776-777.

[20] Bonamin LV, Endler PC. Animal models for studying homeopathy and high dilutions: Conceptual critical review, Homeopathy (2010) 99, 37-50.

[21] Rastogi DP*, Saxenat AC, Kumar S. Pancreatic beta-cell regeneration a novel antidiabetic action of C. Indicamother tincture, The British Homoeopathic Journal July 1988. Vol. 77. pp. $147-151$

[23] Sampath S, Narasimhan A, Chinta R, Janardanan Nair KR, Khurana A, Nayak D, Kumar A, Karundevi B. Effect of homeopathic preparations of Syzygium jambolanum and Cephalandra indica on gastrocnemius muscle of high fat and high fructose-induced type-2 diabetic rats, Homeopathy (2013) 102, 160-171.

[24] Pal A, Misra BB, Das SS, Gauri SS, Patra M, Dey S. Antidiabetic effect of Cephalandra indica Q in diabetic rats. Indian J Res Homoeopathy 2013;7(2):81-90. 
[25] Muthuviveganandavel S, Veerappan M, *Pandurangan M. Efficacy of Cephalandra indica mother tincture on the biochemical parameter of male albino rat. World Journal of Pharmacy and Pharmaceutical Sciences, Volume 3, Issue 8, 498-504.

[26] Tupe RS, Kulkarni A, Adeshara K, Shaikh S, Shah N, Jadhav A. Syzygium jambolanum and Cephalandra indica homeopathic preparations inhibit albumin glycation and protect erythrocytes: an in vitro study, Homeopathy (2015) 104, 197-204

[27] Kishore L, Singh R. Effects of different homeopathic potencies of $C$. Indica in treatment of neuropathic pain in streptozotocin induced diabetes. Bulletin of Faculty of Pharmacy, Cairo University 55 (2017) 273-280

[28] Kishore L, Singh R. Effect of Cephalandra indica against advanced glycation end products, sorbitol accumulation and aldose reductase activity in homoeopathic formulation. Indian J Res Homoeopathy 2018; 12:11-9.

[29] Nair AB, Jacob S. A simple practice guide for dose conversion between animals and human. J Basic Clin Pharma 2016; 7:27-31.

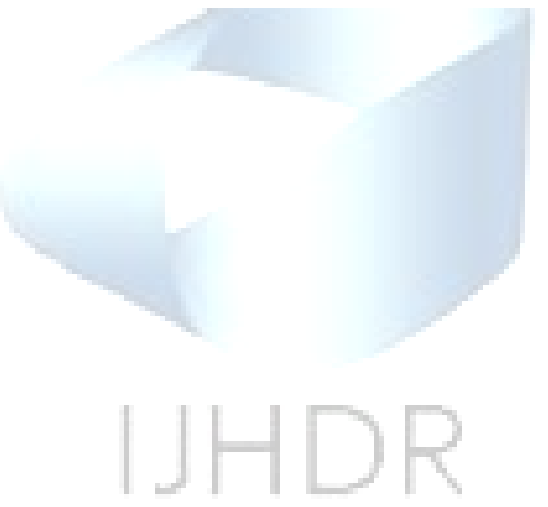

Received: Jul 21, 2019. Accepted: Sep 19, 2019.

(C) International Journal of High Dilution Research.

Not for commercial purposes. 